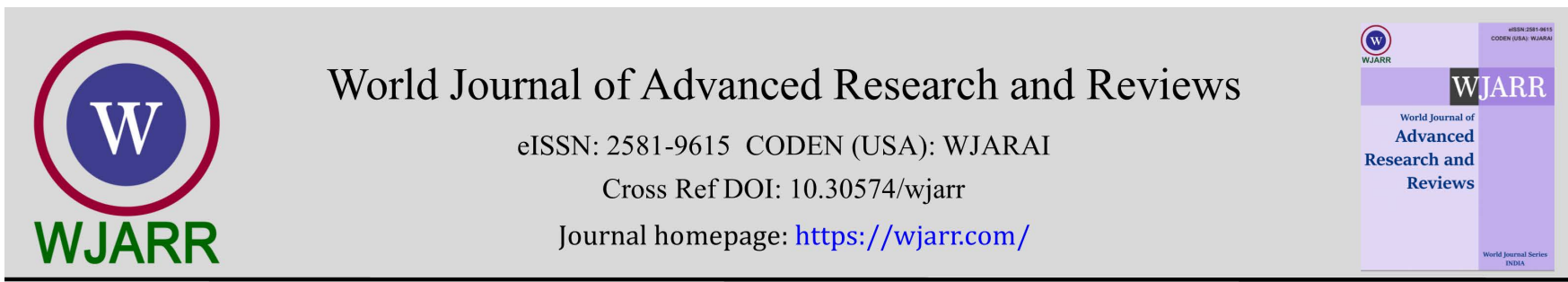

(RESEARCH ARTICLE)

\title{
Same useful fixative from resin in Vietnam
}

\author{
Le Huy Hai ${ }^{1, *}$, Le Mai Xuan Truc ${ }^{2}$ and Nguyen Quoc Trung ${ }^{3}$ \\ ${ }^{1}$ Faculty of Chemical Engineering and Food Technology, Nguyen Tat Thanh University, Viet Nam. \\ ${ }^{2}$ Faculty of Chemical Engineering and Food Technology, Ho Chi Minh City University of Technology (HCMUT), Viet Nam. \\ ${ }^{3}$ Faculty of Chemistry, VNUHCM-University of Science, Ho Chi Minh City, Viet Nam.
}

World Journal of Advanced Research and Reviews, 2021, 10(03), 088-094

Publication history: Received on 18 April 2021; revised on 06 June 2021; accepted on 08 June 2021

Article DOI: https://doi.org/10.30574/wjarr.2021.10.3.0238

\begin{abstract}
Today, fixatives from natural raw materials are gradually replacing fixatives synthesized from chemicals. The arm of this research is the study of same useful resin in Vietnam for fixative substance in blending fragrance. We obtained Benzoin resin from Styrax tonkenensis Pierre plant in Ha Giang province, Canarium resin from Canarium Album L. in Dak Nong district, Dak Lak province, and Agarwood pulp of Aquilaria crassna plant in Binh Thuan province Vietnam. The material used in the experiment for the natural fragrance was taken from the project of Vietnam essential oils and related natural products. The method of this process is resin extraction by volatile solvents. The resin is dissolved in alcohol 96\% and the distilled alcohol is removed to obtain absolute. The method of assessment of product quality in this study is using the olfactory to assess the odour of samples over time. Benzoin resin, Canarium resin, and Agarwood resin of Vietnam are useful fixatives in blending fragrance. The fixative ability of Benzoin resin absolute is not equal to the ability of Agarwood resin absolute but better than the ability of Canarium resin absolute. Through research and experiment, we can see Benzoin resin, Canarium resin and Agarwood resin are precious. They can be used as a good fixative in aromatherapy. This is a natural resin, a kind of resource available in Vietnam. Therefore, it is recommended for further research, exploitation, and effective use of this resource.
\end{abstract}

Keywords: Agarwood; Benzoin; Canarium; Extraction; Natural fixative

\section{Introduction}

Vietnam is a country with a tropical monsoon climate, so it is very suitable for plants with essential oils and aromatic resin to grow. The aromatic resin obtained from a plant contains resinzing compounds, so it has good fixative capacity in blending fragrance. Fixative is an important area it determines the value of odour especially for perfume. There are many types of fixative substances from the animal, plant, and artificial chemicals used in the field of fragrance. Many types of aromatic resins have been studied and used in fragrance as Benzoin resin, Copaiba balsam, Gurjun balsam, Myrrh resinoid, Oakmoss resinoid, Olibanum resinoid, Styrax resinoid, Tolu balsam resinoid, Treemoss resinoid, Canariun resin, Agarwood resin ... Among these aromatic resins, Benzoin resin, Canariun resin, Agarwood resin are in Vietnam.

Benzoin resin is a valuable raw material for the processing of incense in perfumery technology, extracting benzoic acid, used in medicine and industry. There are two popular types of Benzoin as Benzoin Siam and Benzoin Sumatra [1]. There have been many studies on bioactive [2], therapeutic effect [3]. The chemical compositions of Benzoin resin are Benzoic acid, Cinnamic acid, Vanillin, Benzyl benzoate, Cinnamyl cinnamate, Benzyl cinnamate, Coniferilic alcohol, and Siaresinolic acid $[4,5,6]$.

\footnotetext{
${ }^{*}$ Corresponding author: Le Huy Hai

Faculty of Chemical Engineering and Food Technology, Nguyen Tat Thanh University, Viet Nam.

Copyright (C) 2021 Author(s) retain the copyright of this article. This article is published under the terms of the Creative Commons Attribution Liscense 4.0.
} 
Canarium plant includes about 75 species of plants mainly found in Asia and the Pacific, and several species in Africa. Economic benefit of Canarium plant is the production of resin, which is used for fragrances and aromas [7]. Rapeseed resin is used to treat chest pain, joint pain, and ulcer wounds [8]. The composition of essential oils obtained from the resin of the Canarium plant are Monoterpenoids and Sesquiterpenoids with Limonene, Sabinene, Elemicin, $\beta$ phellandrene, $\beta$-pinene, $\alpha$-terpinene, $\gamma$-terpinene and Terpinen-4-ol as main ingredients. New substances in the chemical composition of Canarium Album L. have antioxidant effects that continue to be discovered [9, 10, 11].

Aromatherapy from agarwood resin is a valuable ingredient and is used in traditional medicine, perfumes and cosmetics. Many studies have been done to analyze their quality. Agarwood resin is extracted using various solvents. However, for ingredients with non-volatile aromatics composition, the distillation method cannot extract the resin fraction [12]. These substances must use a suitable solvent to extract from frankincense. The chemical composition of agarwood resin is a complex mixture of Monoterpene, Sesquiterpenes and its common derivatives [13]. Sesquiterpenes are the main ingredients, important in creating the aroma and pleasant smell of frankincense [14]. The resin and polymer compounds found in frankincense are good ingredients for fixative substances.

The purpose of our research is to evaluate the fixative ability of some useful resin in Vietnam for the fragrance field. The study of resin fixatives is of great scientific and practical significance. In terms of science, it is making a significant contribution to the field of fragrance creation, this is a new and less researched field in Vietnam.

\section{Material and methods}

\subsection{Material}

We obtained Benzoin resin from Styrax tonkenensis Pierre plant in Ha Giang province, Canarium resin from Canarium Album L. in Dak Nong district, Dak Lak province, and Agarwood pulp of Aquilaria crassna plant in Binh Thuan province Vietnam. The material used in the experiment for the natural fragrance was taken from the project on Vietnam essential oils and related natural products. In our experiments, we used the volatile solvent is a solvent of alcohol $96 \%$, and an odourless solvent diethyl phthalate (DEP).

\subsection{Method of creating absolute resin}

\subsubsection{Method of creation Benzoin resin absolute and Canarium resin absolute}

The raw resin is extracted by a solvent at room temperature, the aromatic compounds in the raw material will be dissolved in the solvent. Distilled at low pressure to remove solvents we obtain Benzoin resin absolute.

\subsubsection{Method of creation Agarwood resin absolute}

Agarwood resin absolute is extracted from Agarwood pulp by Soxhlet. The solvent was boiled and condensed through Agarwood pulp and dissolved odourants in Agarwood pulp. After extraction, we distillate to isolate solvent at low pressure to obtain the Agarwood resin absolute.

\subsubsection{Method of assessment of product quality}

Table 1 Descriptive statistics on the ability to retain odour by smell

\begin{tabular}{|c|l|c|}
\hline Rating level & \multicolumn{1}{c|}{$\begin{array}{c}\text { Classifying odour } \\
\text { rating }\end{array}$} & Description of the smell \\
\hline 5 & The smell is very strong & The original aroma of the sample \\
\hline 4 & The smell is quite strong & The initial odour is slightly reduced \\
\hline 3 & The smell is average & Smell initially decreased significantly \\
\hline 2 & The smell is weak & The odour was mild \\
\hline 1 & The smell is very weak & The smell was initially very difficult to receive \\
\hline 0 & The smell is gone & The smell did not recognize \\
\hline
\end{tabular}

In the field of fragrance, the smell is mainly measured by the human olfactory. The fragrance is diluted 10-20 times by odourless solvent diethyl phthalate (DEP), then use special paper and olfactory of the nose to evaluate the aroma. Record of odour quality and odour retention time for comparative assessment. 


\section{Results and discussion}

\subsection{Benzoin resin absolute}

There are two common kinds of Benzoin as Benzoin Sumatra and Benzoin Siam. Benzoin Siam is obtained from Styrax tonkinensis, found across Laos, Cambodia, Thailand, and Vietnam.

There are 4 species of Benzoin Siam in Vietnam as Styrax tonkinensis Pierre, Styrax benzoin Dryand, Styrax agrestis G. Don, Styrax annamensis Guill. The most abundant species is Styrax tonkenensis Pierre, growing in midland forests especially in the fields of Hoa Binh, Ha Giang, Tuyen Quang, Lao Cai, Vinh Phu, Lai Chau, Son La, Nghe An, Ha Tinh, and Thanh Hoa province.

Styrax tonkinensis Pierre resin has the local name "Cánh kiến trắng, an tức hương, Bồ đề" belongs to the family Styracaceae. This is a natural resin obtained from the Linden plant in Vietnam.

From 200 grams of crude Benzoin resin is dissolved in 800 grams of ethanol in 24 hours. After filtering and evaporating the solvent, obtained Benzoin resin absolute $158 \mathrm{~g}$ (efficiency 79\%, Table 2).

\subsection{Canarium resin absolute}

Canarium plant is a woody plant about 10-25 m high, with small light brown branches. It is found in southern China such as Guangxi, Guangdong, Yunnan, and Northern Laos. In Vietnam, Canarium plant can live on many types of soil, often found in many parts of the southern provinces. In the North, the plant is found in Hoa Binh province, Ha Tay, Vinh Phuc, Bac Can, Yen Bai, Thai Nguyen, Tuyen Quang. To get the resin, people choose a place 40 - $50 \mathrm{~cm}$ from the ground to the injection site. People use a sharp knife to cut the plant trunk to remove the bark that only touches the wood to get raw resin. Canarium resin after collection is not pre-processing, compressed, and wrapped in plastic bags so that the resin is not exposed to the wind, resin storage in shade.

From 200 grams of crude Canarium resin is dissolved in 800 grams of ethanol in 24 hours. After filtering and evaporating the solvent, obtained Canarium resin absolute $112.64 \mathrm{~g}$ (efficiency 56.32\%).

\subsection{Agarwood resin absolute}

Four species of Agarwood are recorded natural distribution in Vietnam as Aquilaria crassna, Aquilaria baillonnii, Aquilaria banaensis, Aquilaria rugosa. Species Aquilaria crassna is a kind of big timber plant that contains a high volume of Agarwood oil and has been growing popularly in Vietnam.

Table 2 Properties of the Benzoin resin absolute, Canarium resin absolute, Agarwood resin absolute

\begin{tabular}{|c|c|c|c|c|}
\hline No & $\begin{array}{c}\text { Properties of the } \\
\text { absolute extract }\end{array}$ & $\begin{array}{c}\text { Benzoin resin } \\
\text { absolute }\end{array}$ & $\begin{array}{c}\text { Canarium resin } \\
\text { absolute }\end{array}$ & $\begin{array}{c}\text { Agarwood resin } \\
\text { absolute }\end{array}$ \\
\hline 1 & Separation method & By soaking & By soaking & By Soxhlet \\
\hline 2 & Yield\% weight & 79.54 from raw resin & 56.32 from raw resin & $\begin{array}{c}5.56 \text { from Agarwood } \\
\text { pulp }\end{array}$ \\
\hline 3 & Appearance & Yellow colored resin & Dark colored resin & Dark colored resin \\
\hline 4 & Density & 0.989 & 0.9757 & 0.986 \\
\hline 5 & Odour & $\begin{array}{c}\text { Warm, sweet, } \\
\text { chocolate-like, woody } \\
\text { odour of great tenacity }\end{array}$ & $\begin{array}{c}\text { Warm, sweet, woody } \\
\text { odour }\end{array}$ & $\begin{array}{c}\text { Warm, sweet, powdery } \\
\text { woody odour, typical of } \\
\text { agarwood. }\end{array}$ \\
\hline
\end{tabular}

Put in soxhlet $30 \mathrm{~g}$ Agarwood pulp and $300 \mathrm{ml}$ ethanol $96 \%$ into a $500 \mathrm{ml}$ round bottom flask. Heat the ethanol to evaporate and condensate through Agarwood pulp and back to the flask. Continue to cook for up to 4 hours, increasing to $5^{\circ} \mathrm{C}$ each hour, the aromatic ethanol solution is black-brown. Take the extracted solution and add $5 \mathrm{~g}$ of $\mathrm{Na}_{2} \mathrm{SO}_{4}$ to absorb the water in the solution, then allow to settle for 2 hours and filter. The solvent was distilled at $70{ }^{\circ} \mathrm{C}$ and 0.4 
atm, the cooling water was $16{ }^{\circ} \mathrm{C}$. When the solvent evaporation is finished, we have the Agarwood resin absolute product.

\subsection{Using Benzoin resin absolute, Canarium resin absolute, and Agarwood resin absolute as fixative substance}

We created fragrance $\mathrm{B}$, fragrance $\mathrm{C}$, and fragrance $\mathrm{A}$ with similar structures and differences in a fixative note. The fixative substance of fragrance B make from Benzoin resin absolute, the fixative substance of fragrance $C$ make from Canarium resin absolute, the fixative substance of fragrance A make from Agarwood resin absolute. The structure of fragrances includes a top note, body note, and ent note (fixative group). Tope note (top group) make from aldehyde with a powerful odour as Aldehyde C11, Aldehyde C12 lauric, Aldehyde C12 MNA, Aldehyde C14, Aldehyde C16, Aldehyde C20, Cyclamen aldehyde. The main constituents that make up the woody smell are Poumu oil, Sandalwood oil, Cedarwood oil, Aloe wood oil, Vetiver oil, Alpha ionone, Methyl ionone, Galaxolide (Table 3).

Table 3 The composition of aromatic groups

\begin{tabular}{|c|c|c|c|c|c|}
\hline No & Material & $\begin{array}{c}\text { Fragrance B } \\
\text { Wt. \% }\end{array}$ & $\begin{array}{c}\text { Fragrance C } \\
\text { Wt. \% }\end{array}$ & $\begin{array}{c}\text { Fragrance A } \\
\text { Wt. } \%\end{array}$ & Note \\
\hline 1 & Aldehyde C11 & 0.5 & 0.5 & 0.5 & \multirow{7}{*}{ Top note } \\
\hline 2 & Aldehyde C12 lauric & 0.5 & 0.5 & 0.5 & \\
\hline 3 & Aldehyde C12 MNA & 0.5 & 0.5 & 0.5 & \\
\hline 4 & Aldehyde C14 & 0.5 & 0.5 & 0.5 & \\
\hline 5 & Aldehyde C16 & 1 & 1 & 1 & \\
\hline 6 & Aldehyde C20 & 1 & 1 & 1 & \\
\hline 7 & Cyclamen aldehyde & 1 & 1 & 1 & \\
\hline 8 & Poumu oil & 10 & 10 & 10 & \multirow{19}{*}{$\begin{array}{l}\text { Body } \\
\text { note }\end{array}$} \\
\hline 9 & Sandalwood oil & 10 & 10 & 10 & \\
\hline 10 & Cedar wood oil & 10 & 10 & 10 & \\
\hline 11 & Aloe wood oil & 1 & 1 & 1 & \\
\hline 12 & Vetiver oil & 4 & 4 & 4 & \\
\hline 13 & Alpha ionone & 5 & 5 & 5 & \\
\hline 14 & Methyl ionone & 5 & 5 & 5 & \\
\hline 15 & Galaxolide & 5 & 5 & 5 & \\
\hline 16 & Hydroxy citronellal & 5 & 5 & 5 & \\
\hline 17 & Heliotropin & 5 & 5 & 5 & \\
\hline 18 & Geraniol & 1 & 1 & 1 & \\
\hline 19 & Geranyl acetate & 1 & 1 & 1 & \\
\hline 20 & Geranyl butyrate & 1 & 1 & 1 & \\
\hline 21 & Geranyl formate & 1 & 1 & 1 & \\
\hline 22 & Citronellol & 1 & 1 & 1 & \\
\hline 23 & Citronellyl acetate & 1 & 1 & 1 & \\
\hline 24 & Citronellyl butyrate & 1 & 1 & 1 & \\
\hline 25 & Citronellyl formate & 1 & 1 & 1 & \\
\hline 26 & Vanillin & 2 & 2 & 2 & \\
\hline
\end{tabular}




\begin{tabular}{|l|c|c|c|c|}
\hline 27 & Lyral & 1 & 1 & 1 \\
\hline 28 & Lilial & 1 & 1 & 1 \\
\hline 29 & Linalool & 2 & 2 & 2 \\
\hline 30 & Linalyl acetate & 1 & 1 & 1 \\
\hline 31 & Linalyl cinnamate & 2 & 2 & 2 \\
\hline 32 & Eugenol & 1 & 1 & 1 \\
\hline 33 & Isoeugenol & 1 & 1 & 1 \\
\hline 34 & Ginger oil & 1 & 1 & 1 \\
\hline 35 & Ylang Ylang oil & 2 & 2 & 2 \\
\hline 36 & Jasmine oil & 1 & 1 & 1 \\
\hline 37 & Extract laurel flower & 2 & 2 & 2 \\
\hline 38 & Citral diethyl acetal & 1 & 1 & 1 \\
\hline 39 & Methyl heptenone & 1 & 1 & 1 \\
\hline 40 & Benzoin resin absolute & 8 & & \multirow{2}{*}{$\begin{array}{c}\text { End note } \\
\text { group }\end{array}$} \\
\hline 41 & $\begin{array}{c}\text { Canarium resin } \\
\text { absolute }\end{array}$ & & 8 & 100 \\
\hline 42 & $\begin{array}{c}\text { Agarwood resin } \\
\text { absolute }\end{array}$ & & & \\
\hline & Total & 100 & 100 & \multirow{2}{*}{} \\
\hline & & & & \\
\hline
\end{tabular}

\subsection{Compare the ability of Benzoin resin absolute, Canarium resin absolute and Agarwood resin absolute}

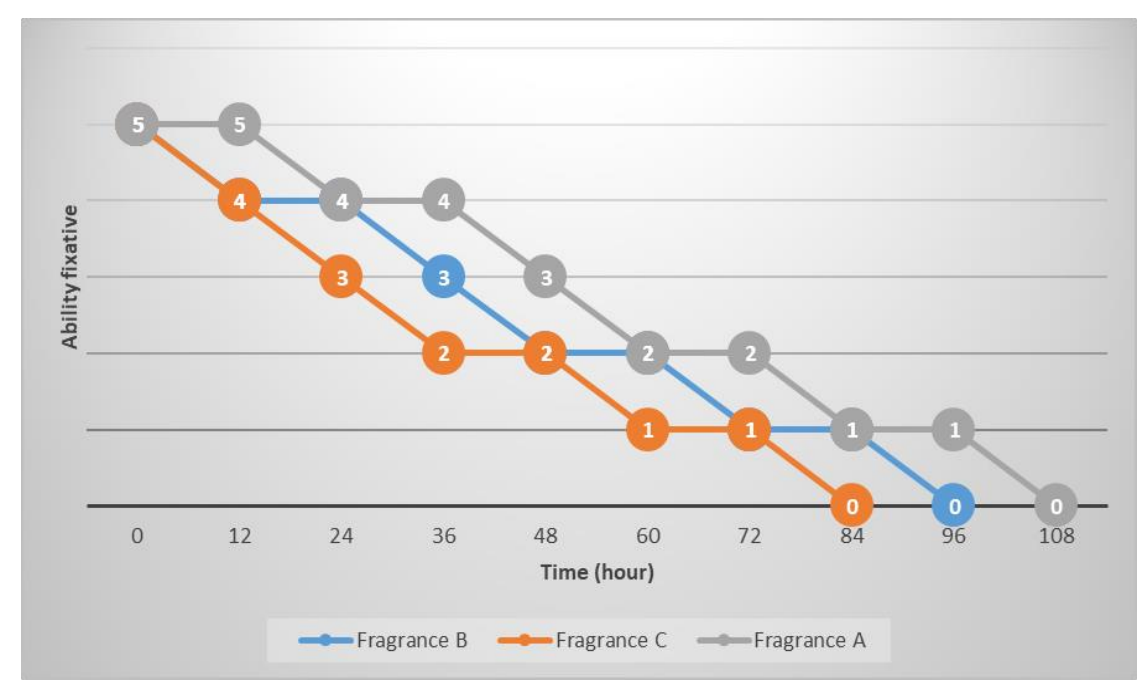

Figure 1 The ability fixative of Benzoin resin absolute, Canarium resin absolute and Agarwood resin absolute

Fig. 1 showed that the ability fixative of fragrance A is the best, losing its smell completely after 108 hours. The ability fixative of fragrance B is better than the ability fixative of fragrance $C$ but not as much as the ability fixative of fragrance A, which loses its smell completely after 96 hours. The ability fixative of fragrance $C$ is the weakest, and it loses its smell completely after 84 hours. 
Table 4 The ability fixative of Benzoin resin absolute, Canarium resin absolute and Agarwood resin absolute

\begin{tabular}{|c|c|c|c|c|}
\hline No & $\begin{array}{c}\text { Time } \\
\text { (hours) }\end{array}$ & Fragrance B & Fragrance $\mathrm{C}$ & Fragrance A \\
\hline 1 & 0 & $\begin{array}{l}\text { The woody odour is very } \\
\text { strong }\end{array}$ & $\begin{array}{l}\text { The woody odour is very } \\
\text { strong }\end{array}$ & $\begin{array}{l}\text { The woody odour is very } \\
\text { strong }\end{array}$ \\
\hline 2 & 12 & $\begin{array}{l}\text { The woody odour is quite } \\
\text { strong }\end{array}$ & $\begin{array}{l}\text { The woody odour is quite } \\
\text { strong }\end{array}$ & $\begin{array}{l}\text { The woody odour is very } \\
\text { strong }\end{array}$ \\
\hline 3 & 24 & $\begin{array}{l}\text { The woody odour is quite } \\
\text { strong }\end{array}$ & The woody odour is average & $\begin{array}{l}\text { The woody odour is quite } \\
\text { strong }\end{array}$ \\
\hline 4 & 36 & The woody odour is average & The woody odour is weak & $\begin{array}{l}\text { The woody odour is quite } \\
\text { strong }\end{array}$ \\
\hline 5 & 48 & The woody odour is weak & The woody odour is weak & The woody odour is average \\
\hline 6 & 60 & The woody odour is weak & The woody odour is poor & The woody odour is weak \\
\hline 7 & 72 & $\begin{array}{l}\text { The woody odour is very } \\
\text { weak }\end{array}$ & $\begin{array}{l}\text { The woody odour is very } \\
\text { weak }\end{array}$ & The woody odour is weak \\
\hline 8 & 84 & $\begin{array}{l}\text { The woody odour is very } \\
\text { weak }\end{array}$ & No more smells & $\begin{array}{l}\text { The woody odour is very } \\
\text { weak }\end{array}$ \\
\hline 9 & 96 & No more smells & No more smells & $\begin{array}{l}\text { The woody odour is very } \\
\text { weak }\end{array}$ \\
\hline 10 & 108 & No more smells & No more smells & No more smells \\
\hline
\end{tabular}

\section{Conclusion}

Benzoin resin, Canarium resin, and Agarwood resin of Vietnam are useful fixatives in blending fragrance. The fixative ability of Benzoin resin absolute is not equal to the ability of Agarwood resin absolute but better than the ability of Canarium resin absolute.

Through research and experiment, we can see Benzoin resin absolute, Canarium resin absolute and Agarwood resin absolute are precious resin. They can be used as a good fixative in aromatherapy. They are natural resin, a kind of resource available in Vietnam. Therefore, it is recommended for further research, exploitation and effective use of this resource.

\section{Compliance with ethical standards}

\section{Acknowledgments}

The authors would like to thank Miss Nguyen Thi Truong Xuan, Mr. Nguyen Ngoc Toan and Nguyen Do An Khang, Faculty of Chemical Engineering and Food Technology, Nguyen Tat Thanh University, Viet Nam.

\section{Disclosure of conflict of interest}

The authors declare that there is no conflict of interest.

\section{References}

[1] Fernandez X, Castel C, Lizzani-Cuvelier L, Delbecque C, Puech Venzal S. Volatile constituents of benzoin gums: Siam and Sumatra, part 3. Fast characterization with an electronic nose. Flavour and Fragrance Journal. 2006; 21: 439-446.

[2] Atia S, Haq N, Rafia R, Ayesha M, Umer R. A review on bioactive potential of Benzoin Resin. International Journal of Chemical and Biochemical Sciences. 2006; 10: 106-110. 
[3] Wang F, Hua H, Pei Y, Chen D, Jing Y. Triterpenoids from the resin of Styrax tonkinensis and their antiproliferative and differentiation effects in human leukemia HL-60 cells. Journal of Natural Products. 2006; 69: 807-810.

[4] Pauline B, Alexandre C, Audrey K, Thomas M, Rémi L, Francis C, Xavier F. New insights in the chemical composition of benzoin balsams. Food Chemistry. 2016; 210: 613-622.

[5] Cecilia C, Xavier F, Louisette L, Christine P, AND Sophie L. Characterization of the Chemical Composition of a Byproduct from Siam Benzoin Gum. Journal of Agricultural and Food Chemistry. 2006; 54: 8848-8854.

[6] Michael H, Paul A, Carole M, Gérald C and Catherine V. Analytical investigation of styrax and benzoin balsams by HPLC-PAD-fluorimetry and GC-MS. Phytochemical Analysis. 2008; 19: 301-310.

[7] Zhen-cheng L, Kang-Chen YZ, Yong-hong P. Nutritional composition of Canarium pimela L. kernels. Food Chemistry. 2011; 125(2): 692-695.

[8] Faijal FM, Aulanni A, Arie S. Influence of Treating Essential Oils of Canarium Tree Resin on The Level Malondialdehyde (MDA), Protease Activity, Bronchi Histopathology Description and Expression of Tumor Necrosis Alpha Factor (TNF- $\alpha$ ) on Asthma Rats (Rattus orvegicus). Journal of Pure and Applied Chemistry Research. 2018; 7(3): 282-291.

[9] Ragunathan M, Senthamarai R. Anti-inflammatory Activity of Essential Oil of Canarium strictum Roxb. Iranian Journal of Pharmaceutical Sciences. 2013; 9(2): 13-21.

[10] Desha M, Nagarajan B, Jesubalan D. Future prospects for the critically endangered medicinally important species, Canarium strictum Roxb, A Review. International Journal of Conservation Science. 2018; 3(3): 231-237.

[11] Suruse PB, Duragkar NJ, Bodele SB, Kale MK. Evaluation of pharma cological activities of isolated triterpenoids from Canarium strictum. International journal of universal pharmacy and life sciences. 2011; 3: 110-119.

[12] Islam MA, Hussain MD, Kabir E, Hasan MZ. Development of low-cost agarwood essential oil extraction system for agar tree growers in Bangladesh. Journal of the Bangladesh Agricultural University. 2014; 12(1): 167-170.

[13] Jong PL, Tsan P, Mohamed R. Gas chromatography-mass spectrometry analysis of agarwood extracts from mature and juvenile Aquilaria malaccensis. International Journal of Agriculture and Biology. 2014; 16: 644-648.

[14] Pripdeevech P, Khummueng W, Park SK. Identification of Odour-active Components of Agarwood Essential Oils from Thailand by Solid Phase Microextraction-GC/MS and GC-O. Journal of Essential Oil Research. 2011; 23: 4653.

\section{Author's short biography}

\begin{tabular}{|l|l|}
\hline & $\begin{array}{l}\text { Dr. Le Huy Hai } \\
\text { Specializing in Blending fragrance trained by the United Nations. } \\
\text { Lecturer for Blending fragrance, Fragrance for cosmetic and Flavor for food. }\end{array}$ \\
\hline
\end{tabular}

